\title{
Preservice Teachers' Views Regarding Out-of-Class Teaching Processes: A Case Study
}

\author{
Ahmet GÖKMEN ${ }^{1}$ \\ ${ }^{1}$ Gazi Faculty of Education, Gazi University, Ankara, Turkey \\ Correspondence: Ahmet GÖKMEN, Gazi Faculty of Education, Gazi University, Ankara, Turkey. E-mail: \\ agokmen@gazi.edu.tr
}

Received: December 29, 2020

Accepted: March 12, 2021

Online Published: April 25, 2021

doi:10.5539/ies.v14n5p74

URL: https://doi.org/10.5539/ies.v14n5p74

\begin{abstract}
Out-of-class learning environments are important learning environments because they improve students' mental and physical health as well as providing them with cognitive, affective, and psychomotor skills. However, it is necessary to make a plan, implement and evaluate the teaching processes appropriately to efficient benefit from out-of-class teaching environments. The present study aimed to determine preservice teachers' views regarding out-of-class teaching processes. The study utilized the case study design, a qualitative research approach, to make an in-depth analysis of preservice teachers' views. 58 preservice teachers from the educational faculty of a state university in Turkey were the participants of the study. Data were collected using a semi-structured interview form developed by the researcher of the present study. For the analysis of data obtained, content analysis was carried out using NVivo9 software, and themes and codes were determined. Findings were presented with frequencies, percentages, excerpts of preservice teachers' views, and models that indicate the relationship between themes and codes. Findings revealed six different themes for the preservice teachers' views: out-of-class learning places; advantages of out-of-class teaching; limitations of out-of-class teaching; planning of out-of-class teaching; implementation of out-of-class teaching; and assessment of out-of-class teaching. The study findings were discussed in line with the related literature and suggestions were made regarding the findings.
\end{abstract}

Keywords: out-of-class learning, out-of-class teaching process, preservice teachers

\section{Introduction}

Technological, economic, environmental, and political advancements in the 21 st century have completely affected educational systems and, therefore, educational methods and techniques. Almost half of the school-age students could not access education and training activities during the COVID19 pandemic period (UNESCO, 2020), which leads to the problem of not reaching education, as a fundamental right (United Nation, 1948). In addition to the limitations of access and challenges of distance education (Yılmaz, 2017; Yıldızhan \& Güçlü, 2019; Rannastu-Avalos \& Siiman, 2020; Yıldız \& Kılıç, 2020) considering social, economic, and most importantly, students' longing for school (Quay et al., 2020), face-to-face is planned to be started by taking the necessary measures in educational institutions. However, it is foreseen that face-to-face education processes will not be the same as before for a long time because students cannot stay indoors for the whole day, in which fresh airflow is limited and social distance rule will be difficult to comply with. Following a prolonged and inactive period for students, it becomes necessary to carry out out-of-class learning activities that will improve their mental health in natural environments (Elliot, 2015; White et al., 2019). Out-of-classroom education is used to be an option before the COVID19 pandemic and teachers who want to carry out these activities did these activities as a result of their efforts. However, it is foreseen that out-of-class activities will be a mandatory educational activity after the COVID19 pandemic.

Out-of-class teaching is an important place in science education (Orion \& Hofstein, 1994). Nevertheless, it is an interdisciplinary structure due to the subjects and content it addresses. Bunting (2006) stated that out-of-class learning needs to include practical activities, establish a connection with the natural environment, constantly encourage reflection, generalization and practice, and build interdisciplinary relationships.

Also, the difference between out-of-class education and informal learning must be emphasized (Öner \& Öztürk, 2019). Informal learning refers to obtaining information through random means without any planning. 
Out-of-class education, on the other hand, is a process that serves specific goals within the scope of educational activities, and it is carried out under the supervision of a guide and requires detailed planning. In this respect, it must be noted that it has the potential to obtain very beneficial results only with an effective planning process (Atmaca, 2012a). Although the literature put forward different and even controversial concepts, the term out-of-class will be used in the present study.

Out-of-class learning can be defined as an instruction method that can be used effectively for students to achieve objectives of the curriculum by performing activities that are difficult or impossible to perform in a classroom outside the classes (Rillo, 1980; Payne, 1985; Bunting, 2006). Out-of-class educational activities support students' attainment of cognitive, affective, and psychomotor objectives, and consider students' interests and expectations, within a certain plan (Binbaşıŏlu, 2000; Gürsoy, 2018).

Bell, Lewenstein, Shouse, and Feder (2009) indicated that out-of-class learning activities will be beneficial to students in.

Boosting their motivation: They learn nature and physical environments with exciting experiences, interest and motivation,

Learning, using new knowledge, and recalling: They develop their skills of comprehension, recalling, using concepts, scientific research techniques,

Scientific process skills: They test their knowledge of nature and physical environment, form hypotheses, ask questions, and observe.

Participating in learning processes: They include science in their learning process through learning and recognizing a concept.

Developing social skills: They scientifically communicate with other individuals in scientific activities,

Creating a scientific identity: They self-evaluate in the domain of learning and create a scientific self-identity.

Out-of-class teaching can be effectively used in transferring high-level objectives in science education such as analysis, synthesis, and evaluation.

The national scientific projects that particular focus on out-of-class training and learning in Turkey, like TÜBİTAK 2237, TÜBİTAK 4004, Nature Education, and out-of-class applications supported by Science Schools (Yokuş, 2020), is increasingly widespread (Karadoğan, 2016). Out-of-class teaching can be performed in many places such as museums, science and art centers, planetariums, botanical parks, which, however, include only one part of the out-of-class learning places (O’Mahony, 2010). Besides, school conference halls, school gardens, and even school corridors can be used to perform out-of-class teaching. Atmaca (2012b) defined out-of-class education considering all the aforementioned points: All of the educational activities planned with individuals of all ages in processes such as 30 minutes, one hour, one day, or one week in places such as school garden, urban parks, farms, forest, or national park, for purposes such as making discoveries for art, geography, history, grammar, music, mathematics, science, or physical education, reaching the facts, socializing, and teaching concepts.

Considering studies in the related literature, studies that examine the effects of out-of-class teaching activities on cognitive objectives with experimental methods outnumbered (Şahin \& Sağlamer Yazgan, 2013; Bozdoğan \& Kavc1, 2016; Bodur \& Yıldırım, 2018; Borsos, Borić, \& Patocskai, 2018; Durel, 2018; Sontay \& Karamustafaoğlu, 2018; Avc1 \& Gümüş, 2020). However, some studies reported that out-of-class activities positively affect objectives in the affective field, which is indeed difficult to observe (Doğan, Çiçek, \& Saraç, 2017; Yavuz Topaloğlu \& Balkan Kıyıcı, 2018; Yıldırım, 2018). Out-of-class learning processes, which are an important part of contemporary education, can include activities lasting from a few minutes to days (Donaldson \& Goering, 1970). Some experimental reported no change in attitudes were also reported, which might stem from the fact that longer periods are needed to change attitudes (Gürsoy, 2018). All the aforementioned points helped to conclude that out-of-class teaching includes cognitive, affective and psychomotor objectives and positively affects these objectives.

Some studies, on the other hand, examined individuals' opinions regarding out-of-class teaching. Bostan Sarıoğlan and Küçüközer (2017) in their study investigated preservice teachers' out-of-class education and found that their participants regard places such as home, circles of friends, private teaching institutions, and study centers as an out-of-class learning place in their study. In their study, the preservice teachers highlighted the contribution of out-of-class learning to permanent learning and also expressed their views regarding the advantages and disadvantages of out-of-class learning. Kubat (2018) conducted a study to investigate preservice 
teachers' opinions on out-of-class learning environments. It was found that the preservice teachers mostly included science centers and science museums as out-of-class learning environments and they least mentioned zoos and planetariums. These preservice teachers highlighted direct experiences by doing and first-hand as the advantages of out-of-class learning and those legal procedures that take a considerable time as the disadvantages of out-of-class learning. They also added that out-of-class learning environments contribute to the attainment of the objectives of the curriculum and to the retention of their learning. Dönel Akgül and Arabacı (2020) in their study stated that out-of-class learning activities require effective planning of teachers and should be motivation-boosting trips and observations for students. They also stated that there is a need for suitable places for out-of-class environments. They argued that out-of-class environments should be integrated into the new educational process and emphasized that financial conditions should be improved and students' participation should be ensured with appropriate planning. Ocak and Korkmaz (2018) in their study found that science and preschool teachers' out-of-class learning environments provide students with learning by doing and permanent learning, concretize abstract information, and contribute to students' development. They also stated the potential for dangerous situations and crowded classrooms as the disadvantages of out-of-class learning. Therefore, it was important to ensure security, to take necessary permissions from administrators and parents, and to provide student and parent participation, according to the preservice teachers. The teachers stated that they cannot find sufficient places for out-of-class activities in the residential site; therefore, places of out-of-class places should be increased. Considering all these points, it is convenient to assert that teachers are not able to adequately use these areas. Tuuling, Oun, and Ugaste (2019) investigated the opinions of teachers regarding preschool teaching in the preschool period and reported that teachers found out-of-class teaching activities useful but do not prefer them. The researchers of the aforementioned study proposed integrating out-of-class learning into national educational programs.

Studies in the related literature generally focused on the benefits or limitations of out-of-class learning and attempted to determine the requirements of more effective out-of-class learning. However, there is a need for more comprehensive studies addressing planning, implementation and assessment stages for preservice teachers in their out-of-class teaching processes.

Planning, implementation, and assessment are essential components of being successful in the objectives specified by a course. Therefore, it is also very important to address these elements together for a successful out-of-classroom teaching activity. Pre-service teachers' self-efficacy is expected to increase when they are given the chance to practice adequately in out-of-class learning environments (Carrier, 2009); therefore, they will be able to overcome the problems they will encounter in out-of-class teaching in their professional life. In this regard, preservice teachers' views regarding out-of-class learning on the subject are important. Therefore, the present study investigated preservice teachers' views regarding out-of-classroom learning.

\section{Method}

In this section of the study, the model of the study, participants, data collection tools, data analysis, and validity and reliability studies were presented.

\subsection{Model of the Study}

The present study investigated the views of preservice biology teachers regarding out-of-class learning processes. To make a systematic and in-depth analysis of preservice teachers' views (Chmiliar, 2010; Merriam, 2013), the study utilized the case study design, a qualitative design.

The study sought an answer to its questions of how and why without interfering with out-of-class learning situations, and without making any comparison, the categories of events and behaviors were attempted to be defined (Hancock \& Algozzine, 2006). Since the study focused on preservice teachers' views regarding out-of-class learning activities, a holistic single-case design was used, which was analyzed considering a single unit of analysis (Yıldırım \& Şimşek, 2013).

\subsection{Participants}

The participants of the study were selected using the convenience sampling technique. With this sampling technique, studies can be conducted in a more practical way (Yıldırım \& Şimşek, 2013). A total of 58 preservice biology teachers from a public university in Turkey were the participants of the study. The preservice teachers were informed about the study and participated in the study voluntarily. Information regarding the preservice teachers was presented in Table 1. 
Table 1. Information regarding the participants

\begin{tabular}{lccc}
\hline Grade & Gender & $\mathrm{f}$ & $\%$ \\
\hline \multirow{2}{*}{$1^{\text {st }}$ grade } & Female & 14 & 24.1 \\
\cline { 2 - 4 } & Male & 5 & 8.6 \\
\hline \multirow{2}{*}{$2^{\text {nd }}$ grade } & Female & 10 & 17.2 \\
\cline { 2 - 4 } & Male & 4 & 6.9 \\
\hline \multirow{2}{*}{$3^{\text {rd }}$ grade } & Female & 14 & 24.1 \\
\cline { 2 - 4 } & Male & 1 & 1.7 \\
\hline \multirow{2}{*}{$4^{\text {th }}$ grade } & Female & 10 & 17.2 \\
\cline { 2 - 4 } & Male & 0 & 0.0 \\
\hline Total & & 58 & 100 \\
\hline
\end{tabular}

Table 1 included the information regarding the participants of the study. As seen in Table 1, the distribution of the preservice teachers by grade level is: 19 in the first grade (32.7\%), 14 in the second grade $(25.8 \%), 15$ in the third grade $(30.5 \%)$, and 10 in the fourth grade $(17.2 \%)$. Of the participants, 48 were females $(82.7 \%)$ and 10 were males $(17.2 \%)$.

\subsection{Data Collection Tools}

A semi-structured interview form with eight open-ended questions was used to determine the preservice teachers' views on out-of-class learning. In the design of the form, the expert opinions were consulted and the related literature was reviewed. Using the interview technique, it was aimed at the in-depth analysis of the preservice teachers' knowledge and experiences regarding out-of-class learning and addressing all aspects of the subject (Best \& Kahn, 2017; Merriam, 2013). Opinions of five field experts were consulted in the preparation of the form. These field experts were determined considering these criteria: having expertise in qualitative research techniques, coding, and out-of-class learning. Exemplary questions of the interview form were:

- Do you think to apply out-of-class learning activities in your professional life? What kind of activities do you plan in which places with your students?

- Which factors boost your motivation in performing out-of-class learning activities?

- What do you pay attention to while performing out-of-class teaching activities? In what ways do you think these activities differ from other educational activities?

\subsection{Data Collection}

The participants were informed about the interview form, the process of the study in general, and intend addressed in the study. The participants were reminded that they can quit the interview at any time. The preservice teachers' interviews were recorded using a tape recorder upon their permission. All the preservice teachers allowed the use of a tape recorder. Each interview lasted between 6-17 minutes.

\subsection{Data Analysis}

A coding like P1, P2, P3... was assigned to each participant and audio recordings of each participant were labeled. Then, these audio recordings were transcribed, and themes and categories were created. Appropriately assigning each code determined in the transcriptions, it was enabled to check each coding; therefore, the expert opinions were consulted effectively.

Content analysis was used to analyze the data. To secure the reliability of the coding process, three different experts, of whom one was the researcher of the present study, coded the data separately. The consistency of the coding was examined using the formula "Agreement/(Agreement + Disagreement) * 100 " suggested by Miles and Huberman (1994). The inter-coder reliability for the present study was found to be .87. Miles and Huberman (1994) argued that the inter-coder reliability coefficient should be at least .80, which, therefore, indicates that the coding process of the present study is reliable.

The preservice teachers' answers were analyzed using NVivo9 software, and themes and sub-themes were formed. To report the findings clearly, the data were digitized, and the findings were presented in tables including descriptive statistics. To point the relationship between the preservice teachers' views and the themes created, excerpts of the preservice teachers' views were also provided for each theme. The model of the thematic coding regarding the preservice teachers' views about out-of-class learning processes was presented in Figure 1. 


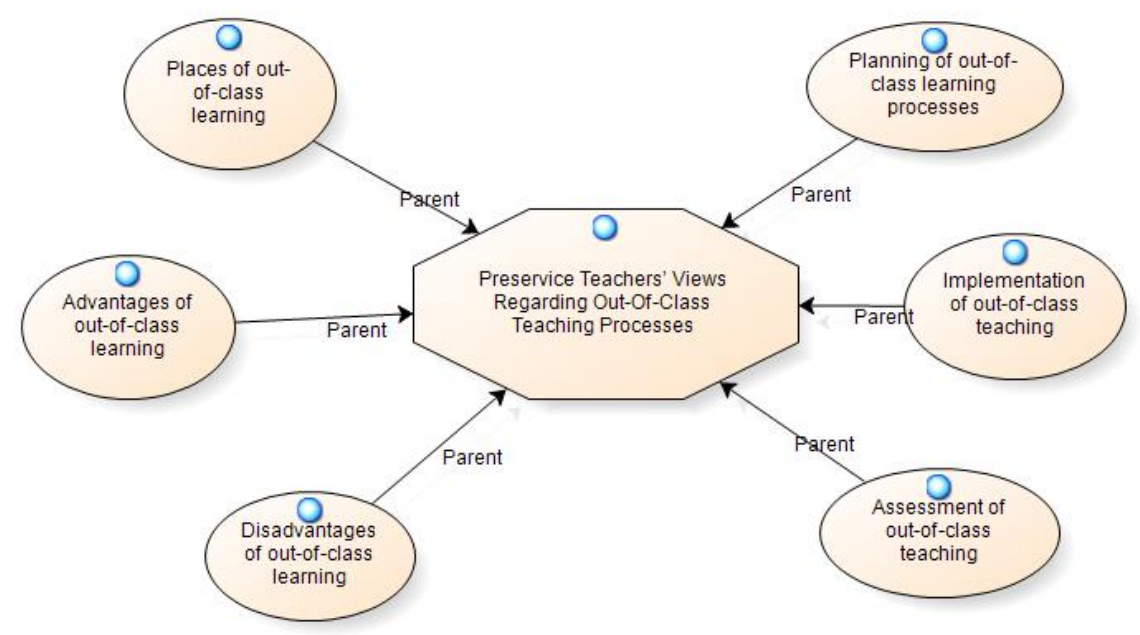

Figure 1. Themes distribution of the preservice teachers' views regarding out-of-class learning processes

The preservice teachers' views regarding out-of-class learning processes were collected under six main themes. Codes and excerpts of each theme were provided in the findings section.

\subsection{Validity and Reliability Studies}

The criteria in qualitative studies will eliminate subjectivity and, therefore, directly affect the processes and results of these studies (Whittemore, Chase \& Mandle, 2001). For this reason, validity and reliability studies were also made for this study (Yıldırım \& Şimşek, 2013).

The opinions of the experts were consulted in the process of developing the interview form, the data collection tool of the present study, and with these opinions, the face validity of the study was ensured.

The external validity of the study; that is, the data obtained from reflecting the relevant situation correctly, were discussed according to the research problems. The audio recordings were listened to and confirmed with the external experts, and a potential bias was tried to be prevented. For internal validity, which is expressed as the dimension of defining data, in-depth information was obtained through the interviews and participant confirmations were applied. In addition, excerpts of each theme were also included.

To ensure the external reliability of the study, the role of the researcher in the present research process was first explained, the processes through which the study was completed, how the data were collected, and the data analysis processes were presented in detail. Regarding internal reliability, the opinions of the independent experts were consulted in the analysis of the data of the research, and the inter-coder reliability calculations were appropriately performed.

\section{Findings}

In this section of the study, the themes obtained as a result of the content analysis, the codes of these themes, and the excerpts of the preservice teachers' statements were presented.

The preservice teachers' views regarding the places of out-of-class learning activities were given in Table 2. 
Table 2. Preservice teachers' views regarding the places of out-of-class learning

\begin{tabular}{lcc}
\hline Codes & f & $\%$ \\
\hline Science centers & 23 & 39.6 \\
Museums & 21 & 36.2 \\
Botanical parks & 17 & 29.3 \\
Zoos & 13 & 22.4 \\
National Parks & 11 & 18.9 \\
University campuses & 9 & 15.5 \\
School gardens & 8 & 13.7 \\
Parks-recreation areas & 6 & 10.3 \\
School corridors & 3 & 5.1 \\
\hline
\end{tabular}

As seen in Table 2, the preservice teachers mostly stated science centers ( $\mathrm{f}=23,39.6 \%)$, museums $(\mathrm{f}=21,36.2 \%$ ), and botanical parks ( $\mathrm{f}=17,29.3 \%)$ as the places of out-of-class learning activities.

Some excerpts of the preservice teachers' statements regarding this theme were:

P28: I would like to take my students to museums. Since the museums are organized, I think we can easily find what we look for.

P41: I think science centers are very important in out-of-class learning. Teachers of science centers can explain concepts more efficiently.

P44: I would use the school garden most. It is both close and less dangerous. Good activities can be performed in school gardens.

The preservice teachers' views regarding the advantages of out-of-class learning were presented in Table 3 .

Table 3. Preservice teachers' views regarding the advantages of out-of-class learning

\begin{tabular}{lcc}
\hline Codes & f & $\%$ \\
\hline Arousing curiosity & 28 & 48.3 \\
Creating an entertaining learning environment & 24 & 41.4 \\
Providing permanent learning & 18 & 31.0 \\
Relating to daily life & 18 & 31.0 \\
Serving to visual senses & 14 & 24.1 \\
Providing the opportunity to practice & 12 & 20.7 \\
To be remarkable & 11 & 19.0 \\
Providing the opportunity to socialize & 9 & 15.5 \\
Providing an effective learning environment & 8 & 13.8 \\
Providing the opportunity to benefit from experts & 8 & 13.8 \\
Embodying knowledge & 7 & 12.1 \\
Developing scientific process skills & 6 & 10.3 \\
Improving organizational and collaboration skills of students & 5 & 8.6 \\
Including environmental protection activities & 4 & 6.9 \\
Making interdisciplinary associations & 3 & 5.1 \\
Ensuring respect for differences & 3 & 5.1 \\
Creating the opportunity to learn about new cultures & 2 & 3.4 \\
Including disadvantaged groups & 2 & 3.4 \\
\hline
\end{tabular}

As seen in Table 3, the preservice teachers mainly highlighted arousing curiosity ( $\mathrm{f}=28 ; 48.3 \%$ ), creating an entertaining learning environment $(\mathrm{f}=24 ; 41.4 \%)$, and providing permanent learning $(\mathrm{f}=18 ; 31.0 \%)$ as the advantages of out-of-class learning.

Some excerpts of the preservice teachers' statements regarding this theme were:

P5: Out-of-class learning will increase students' curiosity and make them eager to learn since they will be in an environment different from the one they are used to.

P13: In a science center or a laboratory, students will have the chance to use and practice the devices and 
instruments there.

P32: Students will not forget what they learned.

The preservice teachers' views regarding the disadvantages of out-of-class learning were presented in Table 4 .

Table 4. Preservice teachers' views regarding the disadvantages of out-of-class learning

\begin{tabular}{lcc}
\hline Codes & $\mathrm{f}$ & $\%$ \\
\hline Failure to provide classroom management & 24 & 41.4 \\
Possible security problems & 20 & 34.5 \\
Time taking & 18 & 31.0 \\
Inability to apply in crowded classes & 16 & 27.6 \\
Increased responsibility towards students & 15 & 25.9 \\
High cost & 14 & 24.1 \\
Problematic weather conditions & 14 & 24.1 \\
Difficult time management & 12 & 20.7 \\
Challenging bureaucratic process & 12 & 20.7 \\
Being difficult for assessment & 11 & 18.9 \\
Difficult transportation & 9 & 15.5 \\
Missing the educational point due to many stimuli & 4 & 6.9 \\
\hline
\end{tabular}

As seen in Table 4, the preservice teachers mainly highlighted failure to provide classroom management ( $\mathrm{f}=24$; $41.4 \%$ ), possible security problems ( $\mathrm{f}=20 ; 34.5 \%$ ), time taking $(\mathrm{f}=18 ; 31.0 \%)$, and inability to apply in crowded classes $(\mathrm{f}=16 ; 27.6 \%)$ as the advantages of out-of-class learning.

Some excerpts of the preservice teachers' statements regarding this theme were:

P17: It will be difficult to control the students during the activities, nobody can hear anyone because there will be too much noise.

P18: Accidents may occur at the destination, students may get injured or disappear.

P29: We can teach the same content with simpler activities. Getting permits and setting up buses is both troublesome and challenging.

The preservice teachers' views regarding the planning of out-of-class learning processes were presented in Table 5.

Table 5. Preservice teachers' views regarding the planning of out-of-class learning processes

\begin{tabular}{llcc}
\hline Codes & & $\mathrm{f}$ & \multicolumn{1}{c}{$\%$} \\
\hline \multirow{4}{*}{ Preparation for the organization $(\mathrm{f}=52 ; 89.6 \%)$} & 19 & 32.8 \\
\cline { 2 - 4 } & Preparation for transportation & 15 & 25.9 \\
\cline { 2 - 4 } & Preparation for cost & 13 & 22.4 \\
\cline { 2 - 4 } & Preparation for undesired situations & 5 & 8.6 \\
\hline \multirow{2}{*}{ Preparation regarding destination $(\mathrm{f}=29 ; 50 \%)$} & 18 & 31.0 \\
\cline { 2 - 4 } & Getting information & 11 & 19.0 \\
\cline { 2 - 4 } & Communication & 23 & 39.7 \\
\hline Identifying the topic of the lesson and the related objectives & 19 & 32.8 \\
\hline Informing students in advance & 16 & 27.6 \\
\hline Analysis of student needs & & \\
\hline
\end{tabular}

As seen in Table 5, the preservice teachers mostly highlighted preparation for organization ( $\mathrm{f}=52 ; 89.6 \%$ ), preparation regarding destination $(\mathrm{f}=29 ; 50 \%)$ and identifying the topic of the lesson and the related objectives $(\mathrm{f}=23 ; 39.7 \%)$ regarding the planning of out-of-class learning processes.

Some excerpts of the preservice teachers' statements regarding this theme were:

P6: Before deciding about the destination, we need to determine for what purpose we will do this activity. The activities, trips, or observations should be related to the objectives.

P46: When will we go? How will you go? Is there an entrance fee? Good planning needs to be made to answer 
all these questions.

P55: We need to inform the administration of the destination in advance of our departure time regarding how many people we will visit. If the destination is an exhibition and more than one school will visit at a time, students can return without experiencing anything.

The preservice teachers' views regarding the implementation of out-of-class teaching were presented in Table 6 .

Table 6. Preservice teachers' views regarding the implementation of out-of-class teaching

\begin{tabular}{lcc}
\hline Codes & $\mathrm{f}$ & $\%$ \\
\hline Observations and experiments should be done & 21 & 36.2 \\
Entertaining activities should be designed & 17 & 29.3 \\
Associations should be made with daily life & 15 & 25.9 \\
Thought-provoking questions should be posed & 14 & 24.1 \\
Attention-grabbing exercises should be done & 12 & 20.6 \\
Hands-on active teaching should be performed & 12 & 20.6 \\
Importance should be attached to individual learning & 8 & 13.7 \\
Instructive activities should be carried out & 7 & 12.0 \\
Expert-guide assistance should be obtained & 5 & 8.6 \\
\hline
\end{tabular}

As seen in Table 6, the preservice teachers mostly highlighted these points regarding the implementation of out-of-class teaching: Observations and experiments should be done $(\mathrm{f}=21 ; 36.2 \%)$; entertaining activities should be designed ( $\mathrm{f}=17 ; 29.3 \%)$; and associations should be made with daily life ( $\mathrm{f}=15 ; 25.9 \%)$.

Some excerpts of the preservice teachers' statements regarding this theme were:

P7: Experiments should be included in out-of-class teaching. Without an experiment, students' knowledge will not be permanent.

P15: Activities to be carried out should be associated with daily life.

P26: Questions that improve students' thinking skills should be posed.

The preservice teachers' views regarding the assessment of out-of-class teaching were presented in Table 7.

Table 7. Preservice teachers' views regarding the assessment of out-of-class teaching

\begin{tabular}{llcc}
\hline Codes & & $\mathrm{f}$ & \multicolumn{1}{c}{$\%$} \\
\hline \multirow{4}{*}{$\begin{array}{l}\text { Traditional assessment methods } \\
(\mathrm{f}=45, \% 77.5)\end{array}$} & Using question-and-answer method & 22 & 37.9 \\
\cline { 2 - 4 } & Making oral exams & 13 & 22.4 \\
\cline { 2 - 4 } & Making written exams & 6 & 10.3 \\
\cline { 2 - 4 } & Posing multiple-choice questions & 4 & 6.9 \\
\hline \multirow{3}{*}{$\begin{array}{l}\text { Alternative assessment methods } \\
(\mathrm{f}=41, \% 70.6)\end{array}$} & Observing & 13 & 22.4 \\
\cline { 2 - 4 } & Keeping a diary & 7 & 12.1 \\
\cline { 2 - 4 } & Creating a portfolio & 5 & 10.3 \\
\cline { 2 - 4 } & Making a process evaluation & 5.6 \\
\cline { 2 - 4 } & Conducting a survey & 5 & 8.6 \\
\hline There is no need for assessment $(\mathrm{f}=5,8.6 \%)$ & & 5 & 8.6 \\
\hline
\end{tabular}

As seen in Table 7, the preservice teachers mostly stated the traditional assessment methods $(\mathrm{f}=45 ; 77.6 \%)$ such as the question-and-answer method or written exams. They also highlighted alternative assessment methods ( $\mathrm{f}=41 ; 70.6 \%)$ such as keeping a diary. On the other hand, some preservice teachers believed that there is no need for assessment in the out-of-class learning teaching processes ( $\mathrm{f}=5 ; 8.6 \%)$.

Some excerpts of the preservice teachers' statements regarding this theme were:

P19: I would pose some questions after the out-of-class teaching. I would answer students' questions and discuss their responses.

P31: I would ask them to keep a portfolio about the activities made in the destination. .... Portfolio. What they saw, what they experienced, what they learned, I would collect all these in a file and then examine these files. 
P53: I would not make any assessment.

\section{Discussion and Conclusion}

This study investigated the preservice teachers' views regarding out-of-class teaching processes. Out-of-class education is a very suitable teaching method for 21 st century skills considering its effect on the acquisition of high-level skills, and the fact that education also keeps pace with out-of-class teaching (Harun \& Salamuddin, 2013).

The preservice teachers primarily stated museums, science centers, and botanical parks as the places of out-of-class activities. Gürsoy (2018) reported that preservice teachers consider this a problem when they do not know the addresses of places where out-of-class teaching activities will be carried out. Similar problems are encountered in different parts of the world. To avoid this situation, Borsos, Borić and Patocskai (2018) stated a list of accessible out-of-class learning places to guide teachers. In the present study, the preservice teachers stated the science centers with the highest frequency among the places where out-of-class learning activities could be carried out, which might be related to the preservice teachers have the chance to visit science centers more easily and to they have already experienced this. According to a study by Kubat (2018), preservice teachers mostly stated science centers and museums for out-of-class learning environments. Similarly, Anagün, Ay, and Demir (2015) in their study reported that preservice teachers defined science centers as out-of-class learning environments. They also stated places such as zoos, natural life parks, and museums as the places that can be used for out-of-class learning activities in science education. In the present study, the preservice teachers also listed university campuses, school gardens, and corridors, even with smaller frequencies, as the places of out-of-class learning processes. This is an important finding of the present study, which is not encountered in the current literature.

Considering the preservice teachers' views about the advantages of out-of-class teaching, it was determined that they primarily emphasized the views of arousing curiosity, creating an entertaining learning environment, and providing permanent learning. Out-of-class learning environments increase students' interest and motivation by taking them out of their usual routines (Eshach, 2007). Similarly, studies indicate that out-of-class teaching increases the permanence of knowledge (Balkan Kıyıcı \& Atabek Yiğit, 2010; Bostan Sarıŏlan \& Küçüközer, 2017; Doğan, Çiçek, \& Saraç, 2018; Mertoğlu, 2019) as students learn by doing and experiencing in the destinations they visit (Martin, 2004; Bozdoğan, Okur, \& Kasap, 2015).

The preservice teachers also highlighted, even with lower frequencies, the social domains such as respect for differences, learning about new cultures, and including disadvantaged groups. Guardino, Hall, Largo-Wight, and Hubbuch (2019) concluded that students with special needs perform their tasks less anxiously and taking more responsibilities in out-of-class learning environments.

Considering the preservice teachers' views regarding the disadvantages of out-of-class activities, they mostly underlined the failure to provide classroom management, possible security problems, and being time-taking. Thomas (2010) stated that teachers have difficulty in controlling students in out-of-class learning environments.

The related literature reported that teachers are aware of the advantages of out-of-class teaching and that out-of-class teaching provides many opportunities; nevertheless, they avoid out-of-class learning activities due to its potential problems (Karadoğan, 2016; Tuuling, Õun, \& Ugaste, 2019). The disadvantages listed by the present study, such as the failure to provide classroom management, potential security problems, time taking, and high cost, are similar to those reported by the related literature (Kubat, 2018; Ocak \& Korkmaz, 2018; Dönel Akgül \& Arabac1, 2020). These disadvantages can only be eliminated by informing preservice teachers regarding out-of-class education and providing them with opportunities to experience it. It is therefore of critical importance to include related courses in teacher education programs and to focus on related competence skills.

The preservice teachers mostly highlighted identifying objectives, preparation for organizations, and preparations for the destination in their views regarding the planning of out-of-class teaching processes.

Ocak and Korkmaz (2018) revealed that preservice teachers expressed these opinions regarding the planning of out-of-class activities: obtaining parental permission, determining the needs of students, considering their interests and requests, and obtaining necessary administrative permissions. Planning is the first and most important step of out-of-class teaching. With a well-planned out-of-class education, objectives can effectively be achieved.

When the preservice teachers' views regarding the implementation of out-of-class teaching, it was determined that they mostly emphasized making observations and experiments, designing entertaining activities, and associating with daily life. One of the most important characteristics that distinguish out-of-class teaching from 
other teaching techniques is the direct participation of the learner without exception and the use of many sensory organs. Studies reported that the more sensory organs participate in the learning process, the more effective learning will take place (Yalın, 1999). The effective attainment of objects depends on hands-on educational activities and the concretization of these activities (Bozdoğan, Okur, \& Kasap, 2015).

When the preservice teachers' views regarding the assessment of out-of-class teaching activities, it was seen that they mostly emphasized the traditional assessment techniques. However, some preservice teachers stated that they will alternative assessment techniques.

The assessment process has many purposes serve many purposes such as making decisions about the success of students at the end of their learning process, providing feedback regarding students' development, determining students' strengths and weaknesses, and deciding about the effectiveness and efficiency of the teaching performed (National Council on Measurement in Education, 1990). Assessment is one of the neglected dimensions of out-of-class teaching processes (James \& Williams, 2017). Ocak and Korkmaz (2018) stated that teachers mostly use the question-and-answer method when evaluating their outside teaching activities. They also stated that some teachers did not make any assessment.

The history of out-of-class learning dates back thousands of years. Nonetheless, it has started to become a method that should be used more than before in the changing and developing world. In the present study that is made to reveal the preservice teachers' views regarding out-of-class learning processes the learning processes of teacher candidates out of the classroom, it is primarily recommended to conduct further studies that will shed light on the concept confusion. In these studies, it should be emphasized that out-of-class learning is well-planned activities that are associated with the curriculum, and is a concept beyond traveling and entertainment.

Another point is the integration of out-of-class learning into the curriculum. There are common elective courses on out-of-class at the educational faculties of universities in Turkey. However, considering the ECTS load and theoretical structure of this course, it is necessary to revise the content of the course in a way that provides more inclusive and to provide more inclusive and applied content.

Out-of-class learning has cognitive, affective, psychomotor, and social benefits. However, the limitations prevent the application of this teaching method. It is recommended to offer holistic solutions to overcome these limitations, to provide the necessary support, to prepare a guide, and most importantly to improve the competencies of educators regarding out-of-class education.

\section{Acknowledgements}

Some parts of this article was presented as an oral paper at the Vth International Eurasian Educational Research Congress, which was held in Antalya/TURKEY between the dates of 2-5 May, 2018.

\section{References}

Anagün, Ş. S., Ay, Y., \& Demir, Z. M. (2015). Sınıf öğretmeni adaylarının fen öğretiminde okul dışı öğrenme hakkındaki görüşleri. Electronic Turkish Studies, $10(15), \quad$ 103-118. https://doi.org/10.7827/TurkishStudies.8702

Atmaca, S. (2012a). Derslik dışı fen etkinlikleri ve bu etkinliklere dayalı öğretimin öğretmen adayları üzerindeki etkileri (Unpublished PhD thesis). Hacettepe Üniversitesi, Sosyal Bilimler Enstitüsü, Ankara.

Atmaca, S. (2012b). Teknolojinin Evrimine Yaratıcı Drama Yöntemiyle Yolculuk: Ödemiş Müzesi. Eğitimci Dergisi. February Issue.

Avc1, G., \& Gümüş, N. (2020). The Effect of Outdoor Education on the Achievement and Recall Levels of Primary School Students in Social Studies Course. Review of International Geographical Education, 10(1), Special Issue, 171-206. https://doi.org/10.33403/rigeo.638453

Balkan Kıyıcı, F., \& Atabek Yiğit, E. (2010). Sınıf duvarlarının ötesinde fen eğitimi: Rüzgâr santrallerine teknik gezi. International Online Journal of Educational Sciences, 2 =(1), 225-243.

Bell, P., Lewenstein, B., Shouse, A. W., \& Feder, M. A. (2009). Learning science in informal environments: People, places, and pursuits (Vol. 140). Washington, DC: National Academies Press.

Best, J. W., \& Kahn, J. V. (2017). Eğitimde araştırma yöntemleri (M. Durmuşçelebi, Trans). Konya: Dizgi Ofset.

Binbaşığlu, C. (2000). Okulda ders dışı etkinlikler. İstanbul: Milli Eğitim.

Bodur, Z., \& Yıldırım, M. (2018). Sınıf dışı etkinliklerinin ortaokul yedinci sınıf öğrencilerinin akademik başarıları ve bilimsel süreç becerileri üzerine etkisi. Marmara Üniversitesi Atatürk Ĕgitim Fakültesi Eğitim 
Bilimleri Dergisi, 47(47), 125-140. https://doi.org/10.15285/maruaebd.271564

Borsos, E., Borić, E., \& Patocskai, M. (2018). Be in: teach outdoors. Croatian Journal of Education, 20(3), 843-866. https://doi.org/10.15516/cje.v20i3.2978

Bostan Sarığlan, A., \& Küçüközer, H. (2017). Fen bilgisi öğretmen adaylarının okul dışı öğrenme ortamları ile ilgili görüşlerinin araştırılması. İnformal Ortamlarda Araştırmalar Dergisi, 2(1), 1-15.

Bozdoğan, A. E., \& Kavcı, A. (2016). Sınıf dışı öğretim etkinliklerinin ortaokul öğrencilerinin fen bilimleri dersindeki akademik başarılarına etkisi. Gazi Eğitim Bilimleri Dergisi, 2(1), 13-30.

Bozdoğan, A. E., Okur, A., \& Kasap, G. (2015). Planlı bir alan gezisi için örnek uygulama: Bir fabrika gezisi. Karadeniz Sosyal Bilimler Dergisi, 7(14), 1-12.

Bunting, C. J. (2006). Interdisciplinary teaching through outdoor education. Newzeland: Human Kinetics.

Carrier, S. J. (2009). The effects of outdoor science lessons with elementary school students on preservice teachers' self-efficacy. Journal of Elementary Science Education, 21(2), 35-48. https://doi.org/10.1007/BF03173683

Chmiliar, 1. (2010). Multiple-case designs. In A. J. Mills, G. Eurepas, \& E. Wiebe (Eds.), Encyclopedia of case study research (pp. 582-583). USA: SAGE Publications.

Doğan, Y., Çiçek, Ö., \& Saraç, E. (2017). Fen bilimleri öğretmen adaylarının çevre bilimi dersi kapsamında gerçekleştirilen alan gezisi deneyimleri. Erzincan Üniversitesi Eğitim Fakültesi Dergisi, 20(1), 104-120. https://doi.org/10.17556/erziefd.346487

Donaldson, G. W., \& Goering, O. H. (1970). Outdoor education: A synthesis. Clearinghouse on Rural Education and Small Schools. Retrieved from https://eric.ed.gov/?id=ED037286

Dönel Akgül, G., \& Arabacı, S. (2020). Okul dışı öğrenme ortamlarının kullanma ve uygulamasına yönelik fen bilgisi öğretmenlerinin görüşleri. Uluslararası Eğitim Araştırmacıları Dergisi, 3(2), 276-291. Retrieved from https://dergipark.org.tr/en/download/article-file/1097386

Durel, E. (2018). Okul dışı fen etkinliklerinin fen bilimleri öğretmen ve ögrretmen adaylart ile ögrrenciler üzerine etkileri (Unpublished master thesis). Trakya Üniversitesi, Edirne.

Elliott, S. (2015). Children in the natural world. In Young children and the environment: Early education for sustainability. Cambridge University Press.

Eshach, H. (2007). Bridging in-school and out-of-school learning: Formal, non-formal, and informal education. Journal of Science Education and Technology, 16(2), 171-190. https://doi.org/10.1007/s10956-006-9027-1

Guardino, C., Hall, K. W., Largo-Wight, E., \& Hubbuch, C. (2019). Teacher and student perceptions of an outdoor classroom. Journal of Outdoor and Environmental Education, 22(2), 113-126. https://doi.org/10.1007/s42322-019-00033-7

Gürsoy, G. (2018). Fen öğretiminde okul dışı öğrenme ortamları. Electronic Turkish Studies, 13(11), 623-649. http://dx.doi.org/10.7827/TurkishStudies.13225

Hancock, R. D., \& Algozzine, B. (2006). Doing case study research. New York: Teachers College Press.

Harun, M. T., \& Salamuddin, N. (2013). Applying elements of outdoor education in teacher education innovation. Asian Social Science, 9(16), 15-21. https://doi.org/10.5539/ass.v9n16p15

James, J. K., \& Williams, T. (2017). School-based experiential outdoor education: A neglected necessity. Journal of Experiential Education, 40(1), 58-71. https://doi.org/10.1177/1053825916676190

Karadoğan, S. (2016). Eğitimde sınıf-okul dışı öğrenme uygulamaları ve yaşanan sorunlar. In R. Aksu (Ed.), Türkiye'de Eğitim Sorunlarına Yönelik Akademik Değerlendirmeler (pp. 47-84). Ankara: Maya Akademi.

Kubat, U. (2018). Okul dış1 öğrenme ortamları hakkında fen bilgisi öğretmen adaylarının görüşleri. Mehmet Akif Ersoy Üniversitesi Eğitim Fakültesi Dergisi, 48, 111-135. https://doi.org/10.21764/maeuefd.429575

Martin, L. M. W. (2004). An emerging research framework for studying informal learning and schools. Science Education, 88(S1), 71-82. https://doi.org/10.1002/sce.20020

Merriam, S. B. (2013). Nitel araştırma: Desen ve uygulama için bir rehber. (3. Press Trans., Ed: S. Turan). Ankara: Nobel Yayın Dağıtım.

Mertoğlu, H. (2019). Fen bilgisi öğretmen adaylarının farklı öğrenme ortamlarında gerçekleştirdikleri okul dışı etkinliklere ilişkin görüşleri. Informal Ortamlarda Araştırmalar Dergisi, 4(1), 37-60. 
Miles, M. B., \& Huberman, A. M. (1994). Qualitative data analysis: An expanded sourcebook. Sage.

National Council on Measurement in Education. (1990). Standards for Teacher Competence in Educational Assessment of Students. Retrieved from https://buros.org/standards-teacher-competence-educationalassessment-students

O'Mahony, T. K. (2010). Connecting formal and informal learning experiences. University of Washington. Retrieved from https://www.researchgate.net/profile/Timothy-Omahony-2/publication/252797254 Connecting_Formal_and_Informal_Learning_Experiences/links/5ed17445299bf1c67d27477f/Connecting-F ormal-and-Informal-Learning-Experiences.pdf

Ocak, İ., \& Korkmaz, Ç. (2018). Fen bilimleri ve okul öncesi öğretmenlerinin okul dışı öğrenme ortamları hakkındaki görüşlerinin incelenmesi. Uluslararası Alan Eğitimi Dergisi, 4(1), 18-38.

Öner, G., \& Öztürk, M. (2019). Okul dışı öğrenme ve öğretim mekânları olarak bilim merkezleri: Sosyal bilgiler öğretmen adaylarının deneyimi. Eskişehir Osmangazi Üniversitesi Sosyal Bilimler Dergisi, 20, 1109-1135. https://doi.org/10.17494/ogusbd.555135

Orion, N., \& Hofstein, A. (1994). Factors that influence learning during a scientific field trip in a natural environment. Journal of research in science teaching, 31(10), 1097-1119. https://doi.org/10.1002/tea.3660311005

Payne, M. R. (1985). Using the outdoors to teach science: a resource guide for elementary and middle school teachers. Educational Resources Information Center, Clearinghouse on Rural Education and Small Schools, New Mexico State University.

Quay, J., Gray, T., Thomas, G., Allen-Craig, S., Asfeldt, M., Andkjaer, S. ... Foley, D. (2020). What future/s for outdoor and environmental education in a world that has contended with COVID-19?. Journal of Outdoor and Environmental Education 23, 93-117. https://doi.org/10.1007/s42322-020-00059-2

Rannastu-Avalos, M., \& Siiman, L. A. (2020). Challenges for distance learning and online collaboration in the time of COVID-19: Interviews with science teachers. International Conference on Collaboration Technologies and Social Computing (pp. 128-142). Springer, Cham. https://doi.org/10.1007/978-3-030-58157-2_9

Rillo, T. J. (1980). Outdoor education--the past is prologue to the future [Conference Proceeding]. New York State Outdoor Education Association, Swan Lake.

Şahin, F., \& Sağlamer Yazgan, B. (2013). Araştırmaya dayalı sınıf dışı laboratuar etkinliklerinin öğrencilerin akademik başarısına etkisi. Sakarya University Journal of Education, 3(3), 107-122.

Sontay, G., \& Karamustafaoğlu, O. (2018). The effect of out-of-school science learning environment on the understanding the nature of science of the 7th grade students in secondary school. Malaysian Online Journal of Educational Sciences, 6(4), 23-31.

Thomas, G. (2010). Facilitator, teacher, or leader? managing conflicting roles in outdoor education. Journal of Experiential Education, 32(3), 239-254. https://doi.org/10.1177/105382590903200305

Tuuling, L., Õun, T., \& Ugaste, A. (2019). Teachers' opinions on utilizing outdoor learning in the preschools of Estonia. Journal of Adventure Education and Outdoor Learning, 19(4), 358-370. https://doi.org/10.1080/14729679.2018.1553722

UNESCO. (2020). School closures caused by Coronavirus (COVID-19). Retrieved from https://en.unesco.org/COVID19/educationresponse

United Nations. (1948). The Universal Declaration of Human Rights. Retrieved from https://www.ohchr.org/EN/UDHR/Documents/UDHR_Translations/eng.pdf

White, M. P., Alcock, I., Grellier, J., Wheeler, B. W., Hartig, T., Warber, S. L., ... \& Fleming, L. E. (2019). Spending at least 120 minutes a week in nature is associated with good health and wellbeing. Scientific reports, 9(1), 1-11. Retrieved from https://www.nature.com/articles/s41598-019-44097-3?fbclid=IwAR3G-raHSnyJ16M_wnVYweU_8GmMgi CyKqWTxpVczI6-F5ZvZMfO8yhiWjQ

Whittemore, R., Chase, S. K., \& Mandle, C. L. (2001). Validity in qualitative research. Qualitative health research, 11(4), 522-537. https://doi.org/10.1177/104973201129119299

Yalın, H. İ. (1999). Öğretim teknolojileri ve materyal gelişstirme. Ankara: Nobel. 
Yavuz Topaloğlu, M., \& Balkan Kıyıcı, F. (2018). Okul dışı öğrenme ortamlarında yürütülen etkinliklerin öğrencilerin sosyobilimsel konulara ilişkin görüşlerine etkisi: Organ bağışı ve GDO. e-Uluslararası Ĕgitim Araştırmaları Dergisi, 9(1), 36-50. https://doi.org/10.24106/kefdergi.2200

Yıldırım, A. \& Şimşek, H. (2013). Sosyal bilimlerde nitel araştırma yöntemleri (9. Baskı). Ankara: Seçkin Yayıncilik.

Yildırım, H. I. (2018). The impact of out-of-school learning environments on 6th grade secondary school students attitude towards science course. Journal of Educationand Training Studies, 6(12), 26-41. https://doi.org/10.11114/jets.v6i12.3624

Yıldız, V. A., \& Kılıç, D. (2020). Pandemi dönemi eğitim süreci ve öğrencilere ilişskin öğretmen ve veli görüşleri. International Conference on Interdisciplinary Educational Reflections (ICIER 2020), Yakın Doğu Üniversitesi, Lefkoşa.

Yıldızhan, Y., \& Güçlü, N. (2019). Eğitim yönetimi uzaktan tezsiz yüksek lisans programlarının öğretim üyeleri açısından değerlendirilmesi. Kuram ve Uygulamada Egitim Yönetimi Dergisi, 25(2), 367-418.

Y1lmaz, R. (2017). Problems experienced in evaluating success and performance in distance education: a case study. Turkish Online Journal of Distance Education, 18(1), 39-51. https://doi.org/10.17718/tojde.285713

Yokuş, G. (2020). Integrating outdoor school learning into formal curriculum: designing outdoor learning experiences and developing outdoor learning framework for pre-service teachers. International Journal of Education Technology and Scientific Researches, 5(13), 1330-1388. https://doi.org/10.35826/ijetsar.276

\section{Copyrights}

Copyright for this article is retained by the author(s), with first publication rights granted to the journal.

This is an open-access article distributed under the terms and conditions of the Creative Commons Attribution license (http://creativecommons.org/licenses/by/4.0/). 